\section{Aggressive prolactinoma in a child related to germline mutation in the ARYL hydrocarbon receptor interacting protein (AIP) gene}

\author{
Prolactinoma agressivo na infância relacionado à mutação \\ no gene da proteína ARYL hidrocarbono (AIP)
}

Luciana Ansaneli Naves', Marie-Lise Jaffrain-Rea ${ }^{2}$,

Sergio Alberto Cunha Vêncio ${ }^{3}$, Clausmir Zaneti Jacomini ${ }^{4}$,

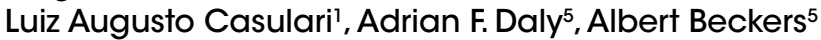

\section{SUMMARY}

The objective of this study was to describe a familial screening for AIP mutations in the context of aggressive prolactinoma in childhood. A 12-year-old boy, presented headaches and bilateral hemianopsia. He had adequate height and weight for his age $\left(50^{\text {th }}\right.$ percentile), Tanner stage G1 P1. His bone age was 10 years. Prolactin was $10.560 \mathrm{ng} / \mathrm{mL}$ (3-25), FSH and LH were undetectable, IGF-1, $\mathrm{TSH}$, FreeT4, ACTH, and cortisol were within normal ranges. MRI showed a pituitary macroadenoma, $5.3 \times 4.0 \times 3.5 \mathrm{~cm}$ with compression of the optic chiasm, bilateral cavernous sinus invasion, encasement of carotids, and extension to clivus. Surgical debulking was performed. Resistance to cabergoline was characterized and he was submitted to two surgeries and radiotherapy. Immunohistochemical evaluation included prolactin, ACTH, GH, FSH, LH,AIP, c-erb B2, Ki-67, and p53. Genomic DNA was isolated from the index case and 48 relatives, PCR and sequencing were performed. A germline A195V mutation in AIP was identified in the index case and in five asymptomatic relatives. Germline mutations in the AIP gene may be involved in the predisposition to pituitary adenoma formation, as cause or co-factor in pathogenesis of aggressive tumors in young patients. Arq Bras Endocrinol Metab. 2010;54(8):761-7

\section{SUMÁRIO}

O objetivo deste estudo foi descrever o rastreamento familiar para mutações AIP em paciente portador de prolactinoma agressivo e resistente na infância. Um menino de 12 anos foi avaliado com queixa de cefaleia e hemianopsia bitemporal. Apresentava peso e altura adequados para a idade (percentil 50), estádio puberal Tanner G1 P1 e idade óssea de 10 anos. Prolactina $10.560 \mathrm{ng} / \mathrm{mL}$ (3-25), FSH e LH indetectáveis, IGF-1, TSH, T4 livre, ACTH, e cortisol normais. A ressonância magnética de sela evidenciou macroadenoma hipofisário, $53 \times 40 \times 35 \mathrm{~mm}$ com compressão de quiasma ótico, invasão de seios cavernosos, envolvimento de carótidas internas e extensão para o clivus. Foi realizada descompressão cirúrgica por via transesfenoidal e caracterizada resistência a doses máximas de cabergolina, sendo o paciente operado por mais duas vezes e submetido à radioterapia. Realizou-se imuno-histoquímica para prolactina, $\mathrm{ACTH}, \mathrm{GH}$, FSH, LH, AIP, c-erb B2, Ki-67 e p53. O DNA genômico foi extraído do caso índice e de 48 familiares, e PCR e sequenciamento. Uma mutação A195V na AIP foi detectada no paciente e em cinco parentes assintomáticos. As mutações no gene da AIP podem estar envolvidas na predisposição à formação de adenomas, como causa ou cofator na patogênese de tumores agressivos em jovens. Arq Bras Endocrinol Metab. 2010;54(8):761-7
Endocrinology Unit, Universidade de Brasília (UnB), DF, Brazil ${ }^{2}$ Experimental Medicine, Univ. of L'Aquila and Neuromed Institute, IRCCS, Pozzilli, Italy ${ }^{3}$ Neuroendocrinology Unity, Hospital Araújo Jorge, Goiânia, Goiás ${ }^{4}$ Hospital Panamericano da Visão Goiânia, GO, Brazil ${ }^{5}$ Endocrinology, Univ. of Liège, Belgium

Correspondence to: Luciana Ansaneli Naves SGAN 605

Av. L2 Norte Hospital Universitário de Brasília, prédio Ambulatórios 2 , Área de Endocrinologia 70840-901 - Brasília, DF, Brazil draluciananaves@gmail.com

Received on Jul/12/2010 Accepted on Nov/23/2010 


\section{INTRODUCTION}

C linically relevant pituitary adenomas have a prevalence of 1 case per 1064-1289 of the population and prolactinomas are the most common comprising $57 \%-66 \%$ of the total $(1,2)$. As with all pituitary adenomas, prolactinomas are unfrequent in childhood, only about $3.5 \%-8.5 \%$ of pituitary adenomas are diagnosed before the age of 20 years and an indolent course may mean that tumors occurring in adolescents are not actually diagnosed until early adulthood $(3,4)$.

Clinical presentation in childhood is variable and symptoms related to tumor growth are the most prevalent. In young children, decrease in growth velocity is a rare symptom, what could contribute to subclinical disease evolution and the delay in diagnosis. Impairment of gonadal axis is the most frequent endocrine disorder in late childhood and adolescence, leading to delayed puberty (4-6).

First-line treatment of prolactinomas relies on dopamine agonists, such as, cabergoline, and relative or complete resistance is very uncommon. Clinical factors associated with tumor aggressiveness and resistance to dopamine agonists include young age at onset, male gender, large tumor size or cavernous sinus invasion at diagnosis (7-10).

Despite many genetic abnormalities being described, the molecular pathophysiology of prolactinomas, particularly those with an aggressive clinical course, remains largely obscure. Recently, germline mutations in the aryl hydrocarbon receptor interacting protein $(A I P)$ gene, were reported to be involved in the predisposition to pituitary adenoma formation $(11,12)$.

Patients with AIP mutations have pituitary adenomas at a younger age, which are often large at diagnosis, suggesting an aggressive phenotype. These tumors usually occur in the familial isolated pituitary adenomas (FIPA) setting $(13,14)$ and sporadic pituitary tumors firstly appeared to be very rare (15-16). Recently, AIP mutations related to sporadic tumors have been increasingly reported in young patients $(17,18)$. In a recently published international collaborative study in 96 patients with pituitary adenomas and AIP mutations, $10.4 \%$ had a familial $A I P$ mutation but no known relatives with pituitary adenomas, and $30.2 \%$ were apparently sporadic cases. Most are somatotropinomas with characteristics that have now been well documented, followed by prolactinomas, and rare non-secreting adenomas (17).

We report here the clinical and pathological features of a young patient with a highly aggressive and invasive prolactinoma that was resistant to dopamine agonists, in whom a germline AIP mutation was identified, and extensive familial screening was performed.

\section{SUBJECTS AND METHODS}

The study was conducted in accordance with the guidelines of the Declaration of Helsinki and genetic analysis was approved by the Ethics Committee of the University of Brasilia. The subjects and guardians provided written informed consent for the genetic and other investigations performed.

\section{Histology and immunohistochemistry}

The tumor specimen was fixed in $10 \%$ formalin and paraffin-embedded. Hematoxylin and eosin staining was performed in all sections. Immunohistochemical evaluation using the Streptavidin-Biotin system (Dako Coorporation, polyclonal antibodies) included prolactin (dilution 1:2000), FSH (clone C10-1:50), LH (clone C93-1:50), TSH (clone 42-1:50), GH (1:2000), ACTH (clone O2A3-1:100), c-erb B2 (oncoprotein C, 1:400), and monoclonal antibodies (Dako Coorporation) were used for Ki-67 (Mib-1, 1:100) and p53 (DO7, 1:50). Mouse monoclonal antibodies directed against AIP (clone 35-2) and AHR (clone RPT9, referred to as "N-mAb") were performed as previously described (18).

\section{Genetic screening}

Genomic DNA was isolated from peripheral blood of the participating subjects. Primers used for the analysis of the AIP exonic and flanking intronic sequences are as reported by Vierimaa and cols. and the PCR reaction/sequencing were performed as reported previously (11-13).

\section{CASE REPORT}

A male patient was firstly evaluated at the age of 12 years, complaining of headaches and visual loss. There was no family history of pituitary adenomas or other endocrine diseases. Physical examination demonstrated adequate height and weight for chronological age $\left(50^{\text {th }}\right.$ percentile), Tanner stage Gl Pl. Bone age was 10 years. Bilateral hemianopsia was confirmed by computed visual field. MRI showed a pituitary macroadenoma, 5.3 X 4.0 $\mathrm{X} 3.5 \mathrm{~cm}$ with compression of the optic chiasm, cystic degeneration of the suprasellar portion, and bilateral 
cavernous sinus invasion with total (left) or near-total (right) encasement of internal carotids, and extension to pontine cistern and clivus (Figure 1). The first prolactin obtained was $226 \mathrm{ng} / \mathrm{mL}$ and after a 1:100 dilution, the hook effect was confirmed and prolactin was $10.560 \mathrm{ng} / \mathrm{mL}$ (normal range $3-25 \mathrm{ng} / \mathrm{mL}$ ), FSH and LH were undetectable, IGF-1, TSH, Free T4, ACTH, and cortisol were within normal ranges for gender and age (Table 1). Due to imminent threat to the patient's vision, surgical debulking via transsphenoidal approach was performed, and tumor volume reduced to $4.3 \mathrm{X} 3.5$ $\mathrm{X} 2.0 \mathrm{~cm}$ (Figure 2). The patient was treated with cabergoline after surgery, starting at a dose of $2 \mathrm{mg} /$ week for two months, $3 \mathrm{mg} /$ week for a further three months and then $3.5 \mathrm{mg} /$ week for two years. However, the lowest prolactin level achieved was $3.792 \mathrm{ng} / \mathrm{mL}$. Tumor size decreased by only a further $20 \%$ after two years of medical treatment (Table 1). The patient was reoperated on

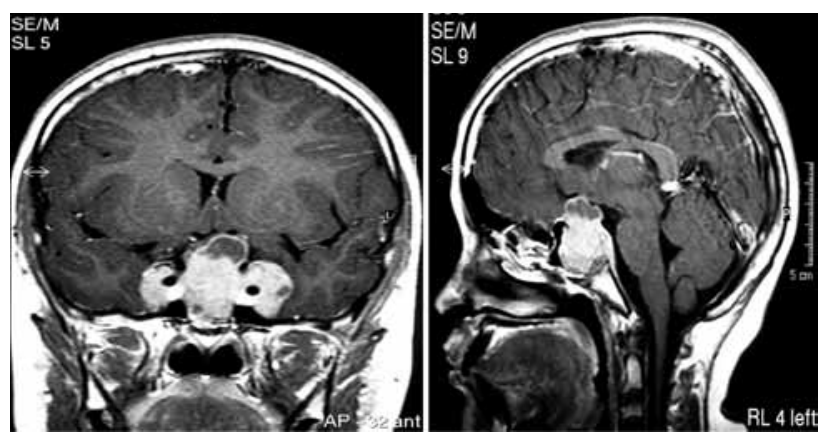

Figure 1. Pre-operatory MRI showed a pituitary macroadenoma, $5.3 \times 4.0$ $X 3.5 \mathrm{~cm}$ with compression of optic chiasm, cystic degeneration of the suprasellar portion, and bilateral cavernous sinus invasion with total (left) or near-total (right) encasement of internal carotids, and extension to pontine cistern and clivus. via the transcranial route, followed by a second transsphenoidal approach one month later, achieving significant debulking, but intracavernous remnants persisted. Fractionated stereotaxic radiotherapy was performed and the linear accelerator-delivered dose of $50.4 \mathrm{~Gy}(5 \times$ 1.8 Gy weekly), with a 2 -mm safety margin was administered. After 10 months of radiation follow-up, at patient's chronological age of 15 years and 10 months, no spontaneous signs of puberty were observed (Tanner Gl P1), his height was $165.5 \mathrm{~cm}$ (Target Height $=171,5$ $\pm 9 \mathrm{~cm}$ ). Bone age was 11 years of age. A thyrotrophic deficiency was detected and levothyroxin $75 \mu \mathrm{g}$ was prescribed. The prolactin nadir after multiple treatments was of 2,198 ng/mL, FSH $1.9 \mathrm{mUI} / \mathrm{mL}$ (pre-pubertal levels < 6), LH $0.5 \mathrm{mUI} / \mathrm{mL}$ (pre-pubertal levels < 5), Testosterone $37 \mathrm{ng} / \mathrm{dL}$ (30-580). Cabergoline treatment was maintained at a dose of 3.5 grams/week, and no growth hormone replacement was prescribed.
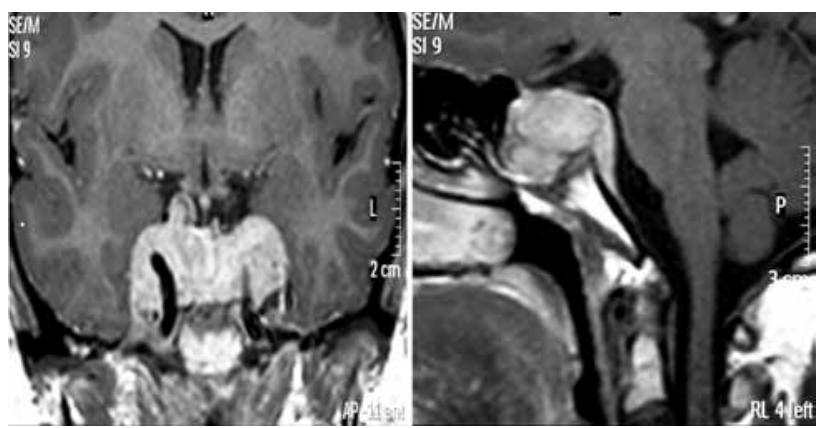

Figure 2. Post-operatory MRI showed a pituitary macroadenoma, $4.3 \times 3.5$ $X 2.0 \mathrm{~cm}$ with bilateral cavernous sinus invasion with total (left) or neartotal (right) encasement of internal carotids, and extension to pontine cistern and clivus.

Table 1. Hormone levels and tumor volume throughout treatment

\begin{tabular}{|c|c|c|c|c|c|}
\hline & Diagnosis & $\begin{array}{l}\text { First surgery } \\
\text { (TSS) }\end{array}$ & $\begin{array}{c}\text { Cabergoline } 3.5 \mathrm{mg} / \mathrm{wk} \\
2 \text { years }\end{array}$ & $\begin{array}{l}\text { Second } \\
\text { approach } \\
\text { (TC + TSS) }\end{array}$ & $\begin{array}{l}\text { Stereotaxic } \\
\text { radiotherapy }\end{array}$ \\
\hline $\begin{array}{l}\text { Chronological } \\
\text { Age }\end{array}$ & $12 y$ & $12 \mathrm{y}, 3 \mathrm{mo}$ & $13 \mathrm{y}, 10 \mathrm{mo}$ & $14 \mathrm{y}, 5 \mathrm{mo}$ & $15 \mathrm{y}, 10 \mathrm{mo}$ \\
\hline Prolactin (2-21 ng/mL) & $\begin{array}{c}\text { Pre-dilution: } 226 \\
\text { Post-dilution: } 10,560\end{array}$ & 6,589 & 3,792 & 3,130 & 2,198 \\
\hline $\mathrm{FSH}(<6 \mathrm{mUI} / \mathrm{mL})$ & 1.8 & 3.3 & 2.1 & 1.3 & 1.9 \\
\hline $\mathrm{LH}(<6 \mathrm{mUl} / \mathrm{mL})$ & 0.1 & 2.2 & 1.5 & 0.5 & 0.5 \\
\hline Testosterone (15-305 ng/dL) & 22.5 & 13.2 & 84.7 & 67.3 & 37 \\
\hline TSH(0,5-5 ulU/mL) & 1.05 & 0.55 & 0.7 & 0.3 & 0.4 \\
\hline FT4 (0.7-1.6 ng/mL) & 1.2 & 1.1 & 1.0 & 0.9 & 1.0 \\
\hline Cortisol (8-25 ng/mL) & 14.0 & 12.9 & 13.8 & 10 & 11.9 \\
\hline ACTH (10-60 pg/mL) & 16.8 & 19.0 & 14.1 & 15.1 & 14.5 \\
\hline IGF-1 (143-693 ng/mL) & 142 & 98.1 & 112 & 141 & 130 \\
\hline Tumor diameter* & $\begin{array}{l}5.3 \times 4.0 \times 3.5 \\
\left(38.76 \mathrm{~cm}^{3}\right)\end{array}$ & $\begin{array}{c}4.3 \times 3.5 \times 2.0 \\
\left(15.72 \mathrm{~cm}^{3}\right)\end{array}$ & $\begin{array}{l}4.0 \times 3.0 \times 2.0 \\
\left(12.54 \mathrm{~cm}^{3}\right)\end{array}$ & $\begin{array}{c}3.5 \times 3.0 \times 1.8 \\
\left(9.87 \mathrm{~cm}^{3}\right)\end{array}$ & $\begin{array}{l}3.0 \times 3.0 \times 1.6 \\
\left(7.54 \mathrm{~cm}^{3}\right)\end{array}$ \\
\hline
\end{tabular}

* Tumor volume was calculated using the Cavalieri principle $4 / 3 \times \pi \times r^{1} \times r^{2} \times r^{3}$. 


\section{Histopathology}

Immunohistochemistry studies have confirmed strong $(+++)$ staining of the tumor for prolactin, and negative staining for FSH, LH, GH, TSH, and ACTH. Ki-67 and p53 labeling indexes were $25 \%$ and $10 \%$ of
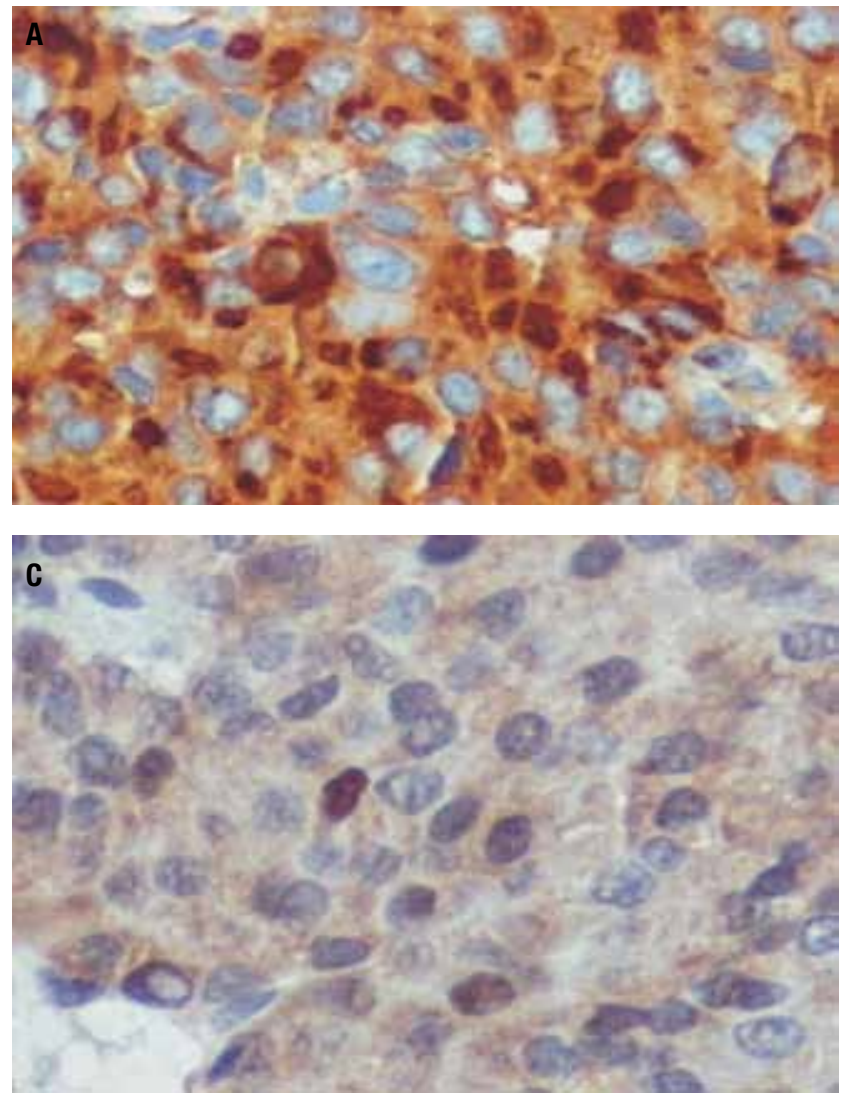

tumor cells, respectively, no membrane immunoreactivity for c-erbB2 was observed (Figure 3). The tumor sample was weakly positive for AIP immunostaining and negative for AHR immunostaining, respectively (Figure 4).
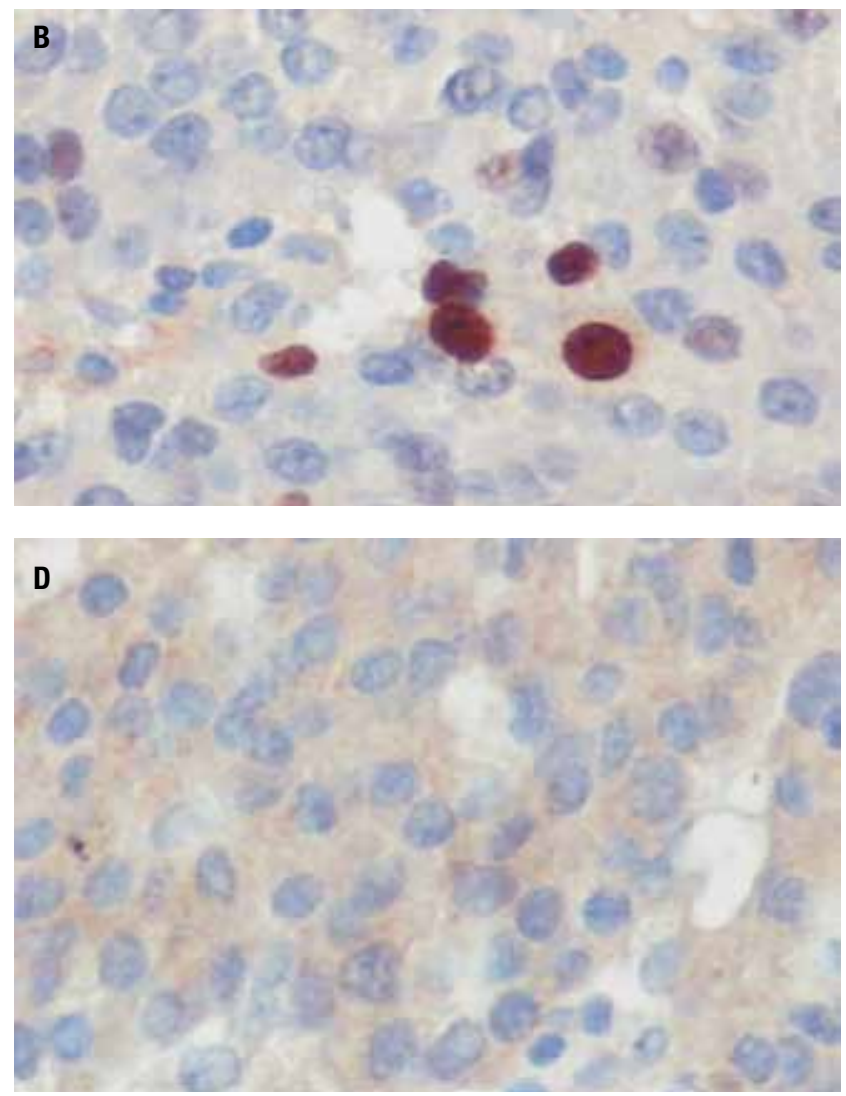

Figure 3. Semiquantitative immunostaining for (a) prolactin (+++/4), (b) KI-67 (++/4), p53-clone D0-7 (+/4) and c-erb B2 (negative). Staining was classified according to the guidelines of Brazilian Society of Pathology:,$+ 10 \%$ cells positive;,$++ 10 \%-25 \%$ cells positive;,$+++ 21 \%-50 \%$ cells positive; ,$++++>50 \%$ cells positive.
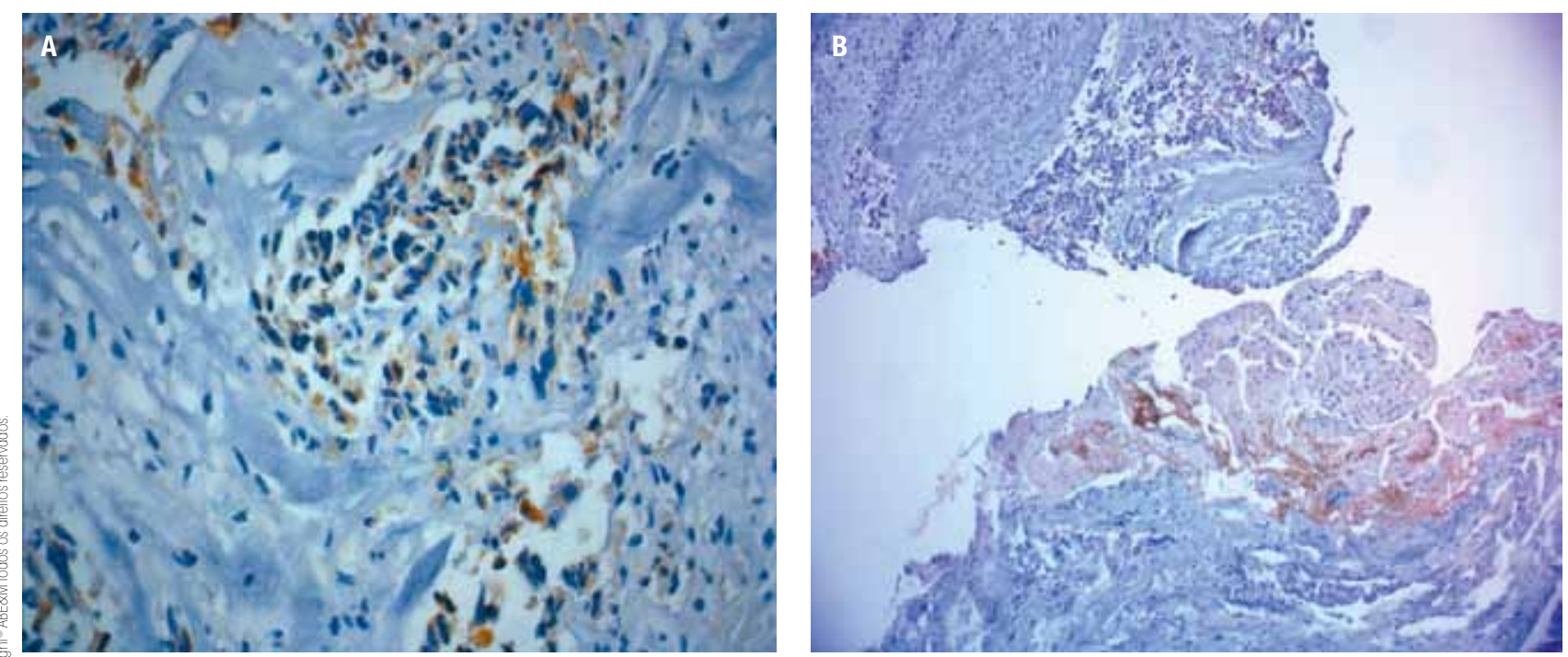

Figure 4. Semiquantitative immunostaining for (A) AIP (X40) and (B) AHR (X10). The AIP staiting was $10 \%$ in adenomatous cells (A) and AHR was negative (B). 


\section{Genetic analyses and familial screening}

In the affected patient a germline A195V mutation in the AIP was identified. Thereafter, comprehensive genealogical data were collected from the family and screening for the mutation was performed in all consenting subjects. The genealogical tree for the family was constructed using Genopro-Beta ${ }^{\circledR}$ program, and comprised 48 individuals in 15 sub-families. Screening identified five additional asymptomatic carriers of the A195V mutation across three generations; the mutation was traced to the maternal grandmother of the index case. In the five asymptomatic A195V mutation carriers, clinical, hormonal (basal prolactin, FSH, LH, cortisol, ACTH, GH, and IGF-1), and radiological (pituitary MRI) screening was performed. No pituitary adenomas have been diagnosed in these five individuals until the present moment.

\section{Study of the frequency of A195V nucleotide changes control individuals in Brazilian population}

We studied 177 control subjects in Brasilia, with no diagnosis of endocrine diseases. These subjects were assessed for the presence of AIP polymorphisms. The $\mathrm{A}-\mathrm{V}$ amino acid substitution at position 195 was not observed in control subjects. These results were compared to 298 non-MENl, non-CNC acromegalic patients, in order to compose the control group database recently published in the context of an international collaborative study (17). Neither in non-AIP mutated acromegalic patients nor in the control subjects, was this A-V substitution observed, therefore the polymorphism at this position was excluded.

\section{Study of the frequency of A195V nucleotide changes in other species}

Genbank was consulted and reported sequences of the AIP protein in other species indicate that it belongs to a highly conserved region. In a minority of aquatic species (Dario Rerio and Xenopus), but not in others (Salmo Salar), the V195 residue is lost together with significant differences in the whole region, strongly suggesting interaction of AIP with different proteins. AIP protein length varies between 328 and 356 amino acids. Of note, the V195A change was not observed in any species (Table 2 ).

\section{DISCUSSION}

Pituitary adenomas in children, although rare, can pose particularly difficult clinical problems when they are invasive or require multi-modal therapy as they can interfere with growth and pubertal development. The search for predictors and prognostic factors is an open field, despite the large number of molecular abnormalities described to date in the pituitary tumor tissue. The current case illustrates many of the existing clinical and pathological challenges in the pediatric pituitary tumor setting. Our patient maintained the growth velocity and adequate height for familial pattern, despite subnormal IGF-1 levels, confirming previous reports that a clinically evident growth deficit is not a common finding in young patients with prolactinoma (19). Delayed puberty related to hyperprolactinemia and gonadotropic deficiency after multiple pituitary interventions was observed and is in accordance with previous case reports. The resistance to treatment with dopamine

Table 2. Comparison between AIP protein sequences among species

\begin{tabular}{|c|c|c|c|}
\hline Species & Genbank & AIP & Sequence Homology around Valine 195 (human) \\
\hline Homo sapiens & NF_003968 & 330 aa & ..mtdeekakavplihgegnrlyreghvkeaaakyydaiaclknlgmkeqpgs.. \\
\hline Macaca mulata & NF_001181242 & 330 aа & ..mtdeekakavplihgegnrlyreghvkeaaakyydaiaclknlgmkeqpgs.. \\
\hline Mus musculus & NF_057875 & 330 aа & ..mtdeekakavpvihgegnrlyreggvkeaaakyydaiaclknlgmkeqpgs.. \\
\hline Rattus norvegicus & NF_758830 & 330 aа & ..mtdeekakavplihgegnrlyreggvkeaaakyydaiaclknlgmkeqpgs.. \\
\hline Bos taurus & NF_898905 & 330 aа & ..mtdeekakavpvihgegnrlyreghvkeaaakyydaiaclknlgmkeqpgs.. \\
\hline Eqqus caballus & NF_001075406 & 356 aа & ..mtdaekakavpvihgegnrlyreghvkeaaakyydaiaclknlgmkeqpgs.. \\
\hline Gallus gallus & NF_989800 & 327 aа & ..mtdeeklqavplihgegnelyrqgkkvreaatkyydaiaclkn1gmkeqpgs.. \\
\hline Salmo salar & NF_001133532 & 342 aа & ..mtddeklevvpqlhvegnalykkgdvkeaaekyhnaiaclknlgmkerpgd. \\
\hline Dario rerio & NF_999877 & 342 aа & ..mtddeklgaipqiheegnalfksgdisgaaekyynaiaclksslqmkerpgd... \\
\hline Xenopus & NF_001096219 & 328 аa & ..mtdgekmeavpvlhgegnglykggktndaaakyyeaiaclkslqmkegpgs. \\
\hline
\end{tabular}

The human V195 residue in the AIP protein sequence is considered to be one of the 10 amino-acids involved in the binding surface of the TPR region (see NP_003968). Reported sequences of the AIP protein in other species indicate that it belongs to a highly conserved region, with polymorphisms being recognized around the V195 residue (indicated in bold red), the V195 residue itself being conserved (highlighted in green). In a minority of aquatic species (Dario Rerio and Xenopus), but not in others (Salmo Salar), the V195 residue is lost together with significant differences in the whole region, strongly suggesting interaction of AIP with different proteins. The AIP protein length varies between 328 and 356 amino-acids. Of note, the V195A change was not observed in any species. 
agonists, specially cabergoline, may be related to dopamine-receptor expression in the adenomatous tissue (7-10), although tumor aggressiveness may be related to $A I P$ mutations in young patients $(12,13)$.

Mutations on AIP may be involved in cell proliferation in several ways: multiple protein-protein interactions may lead in particular to AHR stabilization in the cytoplasm, thereby enhancing its ligand-induced nuclear translocation, and modulation of specific phosphodiesterases in some pituitary cells $(16,20,21)$. The role of endocrine disrupters is a field of interest, and a recent Italian study evaluated the incidence of pituitary tumors in the Seveso population exposed to 2,3,7,8-tetrachlorodibenzo-para-dioxin following an industrial accident in 1976, and no statistically significant increase of incident pituitary tumors was shown in this area (22).

In an unselected series of sporadic pituitary adenoma patients, mutations in AIP are rarely found, $(15,16,23)$. However, as most patients with $A I P$ mutation-related pituitary adenomas present with early onset tumors, screening for germline AIP mutations should be limited to selected groups of sporadic patients, particularly young patients with somatotropinomas or macroadenomas $(17,24)$. In our patient, a V195A missense mutation was observed in the index case. Although no functional studies are available, elements arguing for a pathogenetic mutation include: 1) the lack of V195A alleles among 298 acromegalic patients (17) and 177 Brazilian controls, respectively 2) Valine is highly conserved at 195 position during the evolution, as shown in table $2 ; 3$ ) its identification as one out of the few amino acids involved in the binding surface of the TPR region, which mediates most of the protein-protein interactions of AIP (25).

The same mutation was also be identified in 5 asymptomatic relatives. This suggests a low penetrance of the mutation, as already described in most sporadic cases $(16,17)$. Noteworthy, modifier genes have been proposed to influence the penetrance of AIP mutations in familial and also in sporadic settings (23). In this patient we studied some proliferative markers that are used to define prognosis in several oncologic conditions. The AIP immunostaining was weakly positive in tumor tissue, in accordance with previous reports in non-truncating mutations. However AIP immunostaining does not appear to have any prognostic value in prolactinomas $(18,26)$.

The $\mathrm{Ki}-67$ protein is present in the nucleus of a dividing cell (G1, S, G2/M phase) but is absent from the resting cells (G0 phase). Thus, it can provide some information concerning proliferative potential of cancer cells and about the prediction of response to a certain therapy. Ki-67 labelling in more than $3 \%$ of the cells is commonly associated with tumor invasiveness (27). In GH and PRL secreting adenomas, $\mathrm{Ki}-67$ is generally low in the presence of pre-operative pharmacological treatment (27). In our study we observed positive immunostaining for Ki-67 in about $25 \%$ of tumoral cells, in samples from the first and confirmed in tumor tissue from third surgery. Thus, Ki-67 labelling was conserved after dopamine agonist treatment, and can be considered an additional marker of aggressiveness and pharmacological resistance in our patient.

The tumor suppressor gene p53 controls entry of the cells into the cell cycle, on phase Gl, and mutations on this gene could permit progression of tumor cells. The presence of p53 mutations in pituitary tumors is rarely described (28), but some authors found a relationship with proliferative states $(29,30)$. In our patient we detected positivity in $10 \%$ of the tumoral cells. This finding suggests that p53 would not have an important role in our patient tumor evolution.

The proto-oncogene c-erbB2 encodes a transmembrane receptor protein with tyrosine kinase activity belonging to the epidermal growth factor receptor (EGFR) family. C-erb B2 expression is a marker of tumor aggressiveness in breast cancer (31), but few studies have assessed c-erbB2 in the pituitary. Our group previously reported variable c-erbB2 immunoreactivity in somatotropic and lactotrophic tumors and it might have some influence on their evolution, considering the intimate relationship between c-erb B2 and the epidermal growth factor (EGF) $(28,30)$. We recently described a strong c-erb staining in aggressive somatotropic adenoma in the context of Familial Isolated Pituitary Adenomas (FIPA) with a 174 frameshift AIP mutation (13). In this case, c-erb B2 was negative and had no relation to tumor aggressiveness.

In conclusions, the spectrum of AIP mutation-associated pituitary tumors includes all clinical subtypes. AIP mutations confer an aggressive pituitary tumor phenotype with at an early age onset, and may be screened in childhood-adolescence. AIP mutations are likely to represent co-factors in the pathogenesis rather than the causative abnormality, confer an aggressive pituitary tumor phenotype with early age onset, and may be screened in childhood-adolescence. 
Acknowledgements: We thank Laboratório Sabin and Instituto Sabin in Brasilia-Brazil, for sample preparations and for performing hormonal studies. We thank CNPq for support.

Disclosure: no potential conflict of interest relevant to this article was reported.

\section{REFERENCES}

1. Daly AF, Tichomirowa MA, Beckers A. The epidemiology and genetics of pituitary tumors. Best Pract Res Clin Endocrinol Metab. 2009;23(5):543-54. Review.

2. Beckers A. Higher prevalence of clinically relevant pituitary adenomas confirmed. Clin Endocrinol (Oxf). 2010;72(3):290-1.

3. Kane LA, Leinung MC, Scheithauer BW, Bergstralh EJ, Laws JrER, Groover RV, et al. Pituitary adenomas in childhood and adolescence. J Clin Endocrinol Metab. 1994;79:1135-40.

4. Colao A, Loche S, Cappa M, Di Sarno A, Landi ML, Sarnacchiaro $F$, et al. Prolactinomas in children and adolescents. Clinical presentation and long-term follow-up. J Clin Endocrinol Metab. 1998;83(8):2777-80.

5. Cannavò $S$, Venturino M, Curtò L, De Menis E, D'Arrigo C, Tita $P$, et al. Clinical presentation and outcome of pituitary adenomas in teenagers. Clin Endocrinol. 2003;519-27.

6. Acharya SV, Gopal RA, Bandgar TR, Joshi SR, Menon PS, Shah NS. Clinical profile and long term follow up of children and adolescents with prolactinomas. Pituitary. 2009;12(3):186-9.

7. Verhelst J, Abs R, Maiter D, Vandeweghe M, Velkeniers B, Mockel $\mathrm{J}$, et al. Cabergoline in the treatment of hyperprolactinemia: a study in 455 patients. J Clin Endocrinol Metab. 1999;84:2518-22.

8. Musolino NR, Passos V. Prolactinomas resistentes a agonistas dopaminérgicos: diagnóstico e manejo. Arq Bras Endocrinol Metab. 2005;49(5):641-50.

9. Spinks JJ, Ryan FJ. Cabergoline resistance in pediatric prolactinomas. J Pediatr Hematol Oncol. 2009;31(5):377-9.

10. Delgrange E, Daems T, Verhelst J, Abs R, Maiter D. Characterization of resistance to the prolactin-lowering effects of cabergoline in macroprolactinomas: a study in 122 patients. Eur J Endocrinol. 2009;160(5):747-52. Epub 2009 Feb 17.

11. Vierimaa O, Georgitsi M, Lehtonen R, Vahteristo P, Kokko A, Raitila $A$, et al. Pituitary adenoma predisposition caused by germline mutations in the AIP gene. Science. 2006;312(5777):1228-30.

12. Daly $A F$, Vanbellinghen JF, Khoo SK, Jaffrain-Rea ML, Naves LA, Guitelman MA, et al. Aryl hydrocarbon receptor-interacting protein gene mutations in familial isolated pituitary adenomas: analysis in 73 families. J Clin Endocrinol Metab. 2007;92(5):1891-6.

13. Naves LA, Daly AF, Vanbellinghen JF, Casulari LA, Spilioti C, Magalhães $A V$, et al. Variable pathological and clinical features of a large Brazilian family harboring a mutation in the aryl hydrocarbon receptor-interacting protein gene. Eur J Endocrinol. 2007;157(4):383-91.

14. Daly AF, Tichomirowa MA, Beckers A. Genetic, molecular and clinical features of familial isolated pituitary adenomas. Horm Res. 2009;71 Suppl 2:116-22.

15. Barlier A, Vanbellinghen JF, Daly AF, Silvy M, Jaffrain-Rea ML, Trouillas J, et al. Mutations in the aryl hydrocarbon receptor interacting protein gene are not highly prevalent among subjects with sporadic pituitary adenomas. J Clin Endocrinol Metab. 2007;92(5):1952-5. Epub 2007 Feb 13.
16. Leontiou C, Gueorguiev M, Van der Spuy J, Quinton R, Lolli F, Hassan $\mathrm{H}$, et al. The role of the AIP gene in familial and sporadic pituitary adenomas. J Clin Endocrinol Metab. 2008;93(6):2390-401.

17. Daly AF, Tichomirowa $M$, Petrossians $P$, Jaffrain-Rea ML, Barlier $A$, Naves LA, et al. Clinical characteristics and therapeutic responses in patients with germ-line aip mutations and pituitary adenomas: an international collaborative study. J Clin Endocrinol Metab. 2010;95(11):E373-83.

18. Jaffrain-Rea ML, Angelini M, Gargano D, Tichomirowa MA, Daly AF, Vanbellinghen JF, et al. Expression of aryl hydrocarbon receptor (AHR) and AHR-interacting protein in pituitary adenomas: pathological and clinical implications. Endocr Relat Cancer. 2009;16(3):1029-43.

19. Colao A, Vitale G, Cappabianca P, Briganti F, Ciccarelli A, De Rosa $M$, et al. Outcome of cabergoline treatment in men with prolactinoma: effects of a 24-month treatment on prolactin levels, tumor mass, recovery of pituitary function, and semen analysis. J Clin Endocrinol Metab. 2004;89(4):1704-11.

20. de Oliveira SK, Hoffmeister M, Gambaryan S, Muller-Esterl W, Guimaraes JA, Smolenski AP. Phosphodiesterase 2A forms a complex with the co-chaperone XAP2 and regulates nuclear translocation of the aryl hydrocarbon receptor. J Biol Chem. 2007;282:13656-63.

21. Vandeva $S$, Vasilev V, Vroonen L, Naves L, Jaffrain-Rea ML, Daly $\mathrm{AF}$, et al. The Familial Pituitary Tumors, Ann Endocrinol (Paris). 2010 Oct 18. [Epub ahead of print]

22. Pesatori AC, Baccarelli A, Consonni D, Lania A, Beck-Peccoz P, Bertazzi PA, et al. Aryl hydrocarbon receptor-interacting protein and pituitary adenomas: a population-based study on subjects exposed to dioxin after the Seveso, Italy, accident. Eur J Endocrinol. 2008;159(6):699-703.

23. Toledo RA, Lourenço Jr DM, Toledo SP. Familial isolated pituitary adenoma: evidence for genetic heterogeneity. Front Horm Res. 2010;38:77-86. Epub 2010 Jul 5. Review

24. Jaffrain-Rea ML, Tichomirowa MA, Daly AF, Beckers A. Pituitary adenomas in young patients: when should we consider a genetic predisposition? Expert Rev Endocrinol Metab. 2009;4(6):529-31.

25. Blatch GL, Lassle M. The tetratricopeptide repeat: a structural motif mediating protein-protein interactions. Bioessays. 1999;21(11):932-9.

26. Khoo SK, Pendek R, Nickolov R, Luccio-Camelo DC, Newton TL, Massie A, et al. Genome-wide scan identifies novel modifier loci of acromegalic phenotypes for isolated familial somatotropinoma. Endocr Relat Cancer. 2009;16(3):1057-63. Epub 2009 May 14

27. Jaffrain-Rea ML, Di Stefano D, Minniti G, Esposito V, Bultrini A, Ferretti $E$, et al. A critical reappraisal of MIB-1 labelling index significance in a large series of pituitary tumors: secreting versus non secreting adenomas. Endocrine Related Cancer. 2002;(9):103-13.

28. Levy A, Hall L, Yeudall WA, Lightman SL. P53 gene mutations in pituitary adenomas: a rare events. Clin Endocrinol (Oxf). 1994;41:809-14.

29. Botelho $\mathrm{CH}$, Magalhães AV, Mello PA, Schmitt FC, Casulari LA. Expression of p53, Ki-67 and c-erb B2 in growth hormone-and/ or prolactin-secreting pituitary adenomas. Arq Neuropsiquiatr. 2006;64(1):60-6.

30. Oliveira MC, Marroni CP, Pizarro CB, Lima JFP, Coutinho LMB. Expression of $\mathrm{p} 53$ protein in pituitary adenomas. Braz $\mathrm{J}$ Med Biol Res. 2002;35:561-5.

31. Al-Shraim M, Asa SL. The 2004 World Health Organization Classification of pituitary tumors: what is new? Acta Neuropathol. 2006;111(1):1-7 Review 